\title{
PENGARUH PENAMBAHAN ZAT ADITIF (ENZIM DAN ASAM ORGANIK) DENGAN PROTEIN TINGGI DAN RENDAH PADA PAKAN BERBASIS DEDAK TERHADAP PERFORMAN KELINCI
}

\author{
Prayer F. Polii*, K. Maaruf**, Y. Kowel **, H. Liwe**, Y.C. Raharjo *** \\ ** Fakultas Peternakan, Universitas Sam Ratulangi, Manado 95115 \\ *** Balai Penelitian Ternak Ciawi, Bogor \\ E-mail : poliiprayer@yahoo.co.id
}

\begin{abstract}
ABSTRAK
Penelitian ini bertujuan untuk menguji efektifitas enzim dan asam organik dalam pakan berbasis dedak dengan kandungan protein berbeda terhadap performan produksi kelinci lepas sapih. Penelitian ini dilaksanakan pada bulan Maret sampai Mei 2014 di Balai Penelitian Ternak Ciawi Bogor. Penelitian ini menggunakan 120 ekor kelinci Rex dan Reza lepas sapih berbobot badan $900-1400 \mathrm{~g}$. Rancangan yang digunakan adalah Rancangan Acak lengkap (RAL) pola faktorial (2x4) dengan 5 ulangan. Kombinasi perlakuan terdiri dari Faktor A yaitu level protein : A1 $=14 \%$ Protein dan A2 $=18 \%$ Protein dan Faktor B penambahan aditif (Enzim + Asam Organik) yang terdiri dari : B1 = Pakan Basal; B2 = Pakan Basal + Enzim; B3 = Pakan Basal + Enzim dan Asam Propionat; B4= Pakan Basal + Enzim dan Asam Butirat. Variable yang diamati dalam penelitian ini adalah performan produksi kelinci lepas sapih yaitu : Konsumsi Pakan, Pertambahan Bobot Badan (PBB), dan Konversi Pakan. Konsumsi pakan pada penelitian ini berikisar antara 74,95 - 86,59 g/ekor/hari. Hasil analisis keragaman menunjukkan bahwa perlakuan memberikan pengaruh yang berbeda tidak nyata $(\mathrm{P}>0,05)$ terhadap konsumsi pakan. Pertambahan bobot badan kelinci berkisar antara 11,73 - 16,74 g/ekor/hari. Hasil analisis keragaman menunjukkan bahwa interaksi perlakuan memberikan pengaruh yang berbeda nyata $(\mathrm{P} \leq 0,05)$ terhadap PBB. Hasil uji tukey menunjukan bahwa PBB kelinci yang mendapat pakan A2B3 16,74 g/ekor/hari (18
\end{abstract}

*Alumni Fakultas Peternakan UNSRAT

** Jurusan Nutrisi dan Makanan Ternak UNSRAT
$\%$ protein dengan tambahan Enzim dan Asam Propionat) nyata lebih tinggi dibanding PBB kelinci yang mendapat pakan A1B3 11,73 g/ekor/hari (14\% protein dengan tambahan Enzim dan Asam Organik). Konversi pakan pada penelitian ini berikisar antara 4,93 - 6,60 g/ekor/. Hasil analisis ragam pada penelitian menunjukan bahwa level protein berbeda (14 $\%$ dan $18 \%$ ) dan penambahan zat aditif memberikan pengaruh yang berbeda tidak nyata $(\mathrm{P}>0,05)$, terhadap konversi pakan. Hasil penelitian ini dapat disimpulkan bahwa tidak perlu penambahan feed additive pada ransum yang telah memenuhi kebutuhan zat-zat makanan baik pada level $14 \%$ dan $18 \%$ protein.

Kata Kunci : Kelinci, Dedak, Enzim, Asam Organik

\section{ABSTRACT}

EFFECTS OF ADDITIVES
ADDITION (ENZYMES AND ORGANIC
ACIDS) WITH HIGH AND LOW
PROTEIN IN RICE BRAN BASE RATION
ON RABBIT'S PERFORMANCE A
research evaluating the effectiveness of
enzymes and organic acids in the rice bran-
based with different protein content on the
production performance of weaning rabbits.
This research was conducted in March to May
2014 at the Livestock Research Center Ciawi.
One hundred and twenty rabbits Rex and Reza
of $900-1400 \mathrm{~g}$ body weight. The design used
was factorial (2x4) based on Completely


Randomized Design (CRD) with 5 replications. Combinations treatment consisted of factors, namely the level of protein factor A: $\mathrm{A} 1=14 \%$ protein and $\mathrm{A} 2=18 \%$ protein and factor $\mathrm{B}$ the addition of additives (enzymes + Organic Acids) consisting of: B1 = Ration Basal; B2 = Ration Basal + Feed Enzymes; B3 = Feed Enzymes and propionic acid; B4 = Feed Enzymes and butyric acid. Variables measured were Feed Consumption, Daily Body Weight Gain, and Feed Conversion. Feed consumption in this research were 74.95 to $86.59 \mathrm{~g} / \mathrm{head} / \mathrm{day}$. Analysis of variance showed that there were no significant effects of treatments on feed consumption $(\mathrm{P}>$ 0.05). Daily body weight gain of rabbits ranged from 11.73 to $16.74 \mathrm{~g} / \mathrm{head} /$ day. There was a significant effect of treatment interaction on average daily body weight gain ( $\mathrm{P}<0.05)$. Tukey test showed that Average Daily Gain (ADG) of rabbits fed A2B3 16.74 $\mathrm{g} / \mathrm{head} /$ day $(18 \%$ protein with the addition of enzyme and propionic acid) was significantly higher than the rabbits fed A1B3 11.73 $\mathrm{g} / \mathrm{head} /$ day $(14 \%$ protein with the addition of enzymes and organic acids). The feed conversion in this research is about 4.93 to $6.60 \mathrm{~g} / \mathrm{head} /$ day. There were significant difference among treatment on feed conversion ( $\mathrm{P}>0.05)$. It can be concluded that there is no need of additive supplement when the ration has fulfilled nutrient requirement on $14 \%$ and $18 \%$ protein.

Keywords: Rabbit, Rice Bran, Enzymes, Organic Acids

\section{PENDAHULUAN}

Kelinci merupakan hewan herbivore non ruminansia yang mempunyai system lambung sederhana (tunggal). Kelinci termasuk pada golongan hindgut fermentor yang mengalami pembesaran saluran pencernaan sesudah usus yaitu pada sekum dan kolon yang dihuni oleh mikroba dan berfungsi sebagai tempat proses pencernaan fermentative.
Sistem pencernaannya disebut monogastric functional caecum system. Kelinci, tikus dan hewan pengerat adalah cecal fermentors mempunyai sekum yang membesar. Cecal fermentors dikenal bersifat coprophagy (makan feses malam/feses lunak yang kaya vitamin dan protein mikroba) sehingga sistem kelinci dapat mencerna serat kasar, terutama selulosa dari bahan nabati dengan bantuan bakteri yang hidup didalam sekum (Farrrel dan Raharjo, 1984). Perkembangan kelinci terkendala oleh kurangnya ketersediaan dan rendahnya mutu pakan; disamping itu juga dipengaruhi oleh mutu bibit yang berakibat pada menurunnya produktifitas, mutu produk serta mortalitas anak yang tinggi saat laktasi dan saat lepas sapih.

Pakan untuk kelinci pada skala industri biasanya disusun dari biji-bijian dan alfalfa dalam bentuk pellet tetapi harganya menjadi mahal. Pakan alternatif yang murah dapat menggunakan bahan pakal lokal yang ada disekitar unit produksi dan pengembangan kelinci. Diantara pakan tersebut adalah limbah pertanian/sayuran, dedak, bungkil kelapa, bungkil sawit dan lain-lain. Dedak tersedia dalam jumlah cukup banyak, mudah diperoleh dan telah banyak digunakan untuk pakan kelinci. Penggunaan dedak secara berlebihan perlu diperhatikan karena adanya faktor pembatas. 
Pemakaian zat aditif dalam campuran pakan sudah banyak digunakan di Eropa dengan tujuan unuk meningkatkan nilai gizi ransum. Beberapa peneliti melaporkan bahwa penambahan enzim dalam ransum unggas dan babi dapat meningkatkan nilai nutrisi khususnya pada bahan pakan kualitas rendah. Penambahan enzim juga dapat memecah faktor anti nutrisi (asam fitat) yang terdapat di dalam dedak, sehingga proses penyerapan pakan berlangsung dengan baik (Piliang dkk, 1982). Enzim biasanya ditambahkan pada bahan pakan yang kecernaanya rendah (Mastika, 2000), guna meningkatkan penggunaan bahan pakan tersebut. Pemberian 0,10-0,30\% enzim kompleks dalam pakan secara nyata dapat meningkatkan kecernaan fosfor, pertumbuhan, dan efisiensi penggunaan ransum (Xuan dkk, 2001). Penggunaan enzim protease dan kombinasi proteasexylanase pada pakan kelinci dilaporkan menurunkan tingkat kematian (Garcia dkk, 2005) dan juga penggunaan selulase pada pakan kelinci memperbaiki FCR dan tingkat kematian pada kelinci yang disapih pada usia 23 hari tetapi pertambahan bobot badan rata-rata tidak terpengaruh. Penambahan asam organik dapat menstabilkan bakteri yang ada dalam usus, selain itu dapat juga menurunkan $\mathrm{pH}$ usus sehingga menekan jumlah bakteri patogen dan meningkatkan bakteri nonpatogen terutama bakteri asam laktat (BAL) yang merupakan flora yang menguntungkan pada usus. Berkurangnya bakteri patogen dan meningkatnya BAL maka penyerapan nutrisi dalam usus lebih maksimal (Mastika, 2000). Penambahan enzim dan asam organik pada pakan kelinci diduga dapat pula meningkatkan nilai nutrisi dan penggunaannya untuk peningkatan performan kelinci.

\section{MATERI DAN METODE PENELTIAN}

Penelitian ini dilaksanakan di Balai Penelitian Ternak Ciawi Bogor, pada bulan Maret sampai Mei 2014, dengan menggunakan 120 ekor kelinci Rex dan Reza lepas sapih berbobot badan 900 1400g. Selama percobaan kelinci dipelihara dalam kandang yang terbuat dari kawat berukuran $75 \times 60 \times 60 \mathrm{~cm}$ sejumlah 40 kandang yang dilengkapi dengan tempat makan (feeder) dan tempat minum (trough).

Perlakuan terdiri dari :

- Faktor A, 2 level Protein :

A1 : $14 \%$

A2 : $18 \%$

- Faktor B, Penambahan zat aditif (enzim dan asam organic) :

B1 : Basal/pakan control

B2 : Penambahan Enzim 
B3 : Penambahan Enzim dan Asam Propionat

Sehingga kombinasi perlakuan menjadi

B4 : Penambahan Enzim dan Asam seperti Tabel 1.

Butirat

Tabel 1. Kombinasi perlakuan :

\begin{tabular}{|c|c|c|c|c|}
\hline \multirow{2}{*}{$\begin{array}{l}\text { FAKTOR A } \\
\text { Level Protein }\end{array}$} & \multicolumn{4}{|c|}{$\begin{array}{c}\text { FAKTOR B } \\
\text { Penambahan Aditif }\end{array}$} \\
\hline & $\begin{array}{c}\mathrm{B} 1 \\
\text { (Tanpa aditif) }\end{array}$ & $\begin{array}{r}\mathrm{B} 2 \\
(+ \text { Enzim })\end{array}$ & \begin{tabular}{l}
\multicolumn{1}{c}{ B3 } \\
(+ Enzim \& Asam \\
Propionat)
\end{tabular} & $\begin{array}{c}\text { B4 } \\
\begin{array}{c}\text { (+ Enzim } \& \text { Asam } \\
\text { Butirat })\end{array} \\
\end{array}$ \\
\hline $\mathrm{A} 1(14 \%)$ & A1B1 & A1B2 & A1B3 & A1B4 \\
\hline $\mathrm{A} 2(18 \%)$ & A2B1 & $\mathrm{A} 2 \mathrm{~B} 2$ & A2B3 & A2B4 \\
\hline
\end{tabular}

Tabel 2. Komposisi bahan penyusun ransum

\begin{tabular}{lcccccccc}
\hline Bahan Pakan & \multicolumn{7}{c}{ PERLAKUAN } \\
\cline { 2 - 9 } & $\begin{array}{c}\mathbf{1} \\
\text { (A1B1) }\end{array}$ & $\begin{array}{c}\mathbf{2} \\
\text { (A1B2) }\end{array}$ & $\begin{array}{c}\mathbf{3} \\
\text { (A1B3) }\end{array}$ & $\begin{array}{c}\mathbf{4} \\
\text { (A1B4) }\end{array}$ & $\begin{array}{c}\mathbf{5} \\
\text { (A2B1) }\end{array}$ & $\begin{array}{c}\mathbf{6} \\
\text { (A2B2) }\end{array}$ & $\begin{array}{c}\mathbf{7} \\
\text { (A2B3) }\end{array}$ & $\begin{array}{c}\mathbf{8} \\
\text { (A2B4) }\end{array}$ \\
\hline $\begin{array}{l}\text { Bahan baku pakan (bungkil } \\
\text { kedele, bungkil kelapa, } \\
\text { molases, sekam, pucuk tebu, } \\
\text { coco peat) }\end{array}$ & & & & & & & & \\
\hline Dedak & 47.5 & 47.5 & 47.5 & 47.5 & 62.5 & 62.5 & 62.5 & 62.5 \\
\hline Jagung & 34.8 & 34.8 & 34.8 & 34.8 & 16.2 & 16.2 & 16.2 & 16.2 \\
\hline $\begin{array}{l}\text { makro-mikro mineral + } \\
\text { vitamin }\end{array}$ & 12.5 & 12.5 & 12.5 & 12.5 & 16.1 & 16.1 & 16.1 & 16.1 \\
\hline multi enzim * & 5.1 & 5.1 & 5.1 & 5.1 & 5.1 & 5.1 & 5.1 & 5.1 \\
\hline Asampropionat & 0 & 0.04 & 0.04 & 0.04 & 0 & 0.04 & 0.04 & 0.04 \\
\hline Kalsiumbutirat & 0 & 0 & 0.08 & 0 & 0 & 0 & 0.08 & 0 \\
\hline Dedakgandum & 0.12 & 0.08 & 0 & 0 & 0.12 & 0.08 & 0 & 0 \\
\hline Jumlah & 100 & 100 & 100 & 100 & 100 & 100 & 100 & 100 \\
\hline
\end{tabular}

* Multienzyme mengandung :Cellulase, Xylanase, B-glucanase, phytase, a-mylase, protease, pectinase, lipase. Dosis rekomendasi 350 - $500 \mathrm{~g} / \mathrm{ton}$ 
Tabel 3. Komposisi zat-zat makanan ransum percobaan

\begin{tabular}{|c|c|c|c|c|c|c|c|c|}
\hline \multirow{2}{*}{$\begin{array}{c}\text { ZAT-ZAT } \\
\text { MAKANAN }\end{array}$} & \multicolumn{8}{|c|}{ PERLAKUAN } \\
\hline & $\begin{array}{c}1 \\
\text { (A1B1) }\end{array}$ & $\begin{array}{c}2 \\
\text { (A1B2) }\end{array}$ & $\begin{array}{c}\mathbf{3} \\
\text { (A1B3) }\end{array}$ & $\begin{array}{c}4 \\
\text { (A1B4) } \\
\end{array}$ & $\begin{array}{c}5 \\
\text { (A2B1) } \\
\end{array}$ & $\begin{array}{c}6 \\
(\mathrm{~A} 2 \mathrm{~B} 2) \\
\end{array}$ & $\begin{array}{c}7 \\
\text { (A2B3) } \\
\end{array}$ & $\begin{array}{l}8 \\
\text { (A2B4) }\end{array}$ \\
\hline $\mathrm{CP}(\%)$ & 14.09 & 14.09 & 14.09 & 14.09 & 18.00 & 18.00 & 18.00 & 18.00 \\
\hline $\mathrm{DE}(\mathrm{Kkal} / \mathrm{kg})$ & 2359 & 2359 & 2359 & 2359 & 2594 & 2594 & 2594 & 2594 \\
\hline $\mathrm{CF}(\%)$ & 15.7 & 15.7 & 15.7 & 15.7 & 14.8 & 14.8 & 14.8 & 14.8 \\
\hline $\operatorname{NDF}(\%)$ & 41.34 & 41.34 & 41.34 & 41.34 & 42.28 & 42.28 & 42.28 & 42.28 \\
\hline $\operatorname{ADF}(\%)$ & 18.11 & 18.11 & 18.11 & 18.11 & 18.4 & 18.4 & 18.4 & 18.4 \\
\hline Selulose (\%) & 13.44 & 13.44 & 13.44 & 13.44 & 13.84 & 13.84 & 13.84 & 13.84 \\
\hline ADLignin (\%) & 4.67 & 4.67 & 4.67 & 4.67 & 4.55 & 4.55 & 4.55 & 4.55 \\
\hline sel/lignin (\%) & 2.9 & 2.9 & 2.9 & 2.9 & 3.00 & 3.00 & 3.00 & 3.00 \\
\hline $\mathrm{Ca}(\%)$ & 0.89 & 0.89 & 0.89 & 0.89 & 0.91 & 0.91 & 0.91 & 0.91 \\
\hline $\mathrm{P}(\%)$ & 0.83 & 0.83 & 0.83 & 0.83 & 0.65 & 0.65 & 0.65 & 0.65 \\
\hline Lys (\%) & 0.68 & 0.68 & 0.68 & 0.68 & 0.88 & 0.88 & 0.88 & 0.88 \\
\hline $\operatorname{Met}(\%)$ & 0.49 & 0.49 & 0.49 & 0.49 & 0.41 & 0.41 & 0.41 & 0.41 \\
\hline Try (\%) & 0.23 & 0.23 & 0.23 & 0.23 & 0.26 & 0.26 & 0.26 & 0.26 \\
\hline Thre $(\%)$ & 0.46 & 0.46 & 0.46 & 0.46 & 0.63 & 0.63 & 0.63 & 0.63 \\
\hline
\end{tabular}

Data dianalisis secara statistik menggunakan analisis ragam dengan Rancangan Acak lengkap (RAL) pola faktorial $(2 \times 4)$ menurut Steel dan Torrie (1991) dengan 5 ulangan. Uji Tukey digunakan untuk melihat perbedaan pengaruh perlakuan.

Penelitian ini berlangsung selama 6 minggu 4 hari (46 hari) dibagi atas 2 periode yaitu, periode adaptasi dan periode pengumpulan data.

\section{Periode adaptasi :}

Periode ini berlangsung selama 4 hari, dimana semua kelinci diberi pakan adaptasi secara ad libitum. Pakan ini terdiri dari campuran 8 pakan pelakuan masingmasing perlakuan diambil sebanyak $3 \mathrm{~kg}$ sehingga pakan adaptasi berjumlah $24 \mathrm{~kg}$.
Pada hari ke-4 sore tempat makan diambil dan kelinci dipuasakan semalam.

\section{Periode pengumpulan data :}

Periode ini dimulai pada hari ke-5 setelah kelinci dipuasakan pada malam hari sebelumnya. Kelinci dimasukan ke kandang, 3 ekor per kandangnya, masingmasing kandang berisi kelinci dengan melihat kriteria berat badan (berat, medium, ringan). Penempatan perlakuan ke tiap unit percobaan dilakukan secara acak.

\section{HASIL DAN PEMBAHASAN}

Hasil penelitian tentang pengaruh perlakuan terhadap performa produksi kelinci lepas sapih dapat dilihat pada Tabel 4. 
Tabel 4. Rataan Konsumsi, Pertambahan Bobot Badan (PBB), dan Konversi Pakan.

PERLAKUAN

PERFORMA

Protein $14 \%$

Protein $18 \%$

(Basal)

(E)

$(\mathrm{E}+\mathrm{P}) \quad(\mathrm{E}+\mathrm{B}) \quad($ Basal $)$

(E)

$(\mathrm{E}+\mathrm{P})$

$(\mathrm{E}+\mathrm{B})$

Konsumsi

(g/ekor/hari)

86,3

$79,68 \quad 76,96$

86,59

74,95

78,22

81,00

78,18

(g/ekor/hari)

$13,96^{\mathrm{ab}} 14,13$

$\begin{array}{cc}4,13^{\mathrm{ab}} & 11,73 \\ 5,83 & 6,60\end{array}$

$6,60 \quad 6,33^{\mathrm{a}} \quad 13,8$

$6,34 \quad 60^{\mathrm{ab}} \quad 12,22$

$\begin{array}{lccc}2,22^{\mathrm{ab}} & 14,54^{\mathrm{ab}} & 16,74^{\mathrm{b}} & 14,30^{\mathrm{ab}} \\ 6,25 & 5,42 & 4,93 & 5,48\end{array}$

Ket : nilai dengan superskrip yang berbeda pada baris yang sama menunjukan perbedaan yang nyata $(\mathrm{P}<0,05)$

\section{Konsumsi}

Konsumsi pakan pada penelitian ini berikisar antara 74,95 - 86,59 g/ekor/hari. Hasil penelitian ini ditunjang oleh Aritonang dkk (2003) yang melakukan penelitian pada kelinci Rex, Satin, dan persilangannya, dimana konsumsinya berkisar antara 65,76 88,06 g/ekor/hari. Menurut NRC (1977), faktor-faktor yang mempengaruhi tingkat konsumsi ransum pada ternak kelinci adalah temperatur lingkungan, kesehatan, bentuk ransum, imbangan zat makanan, cekaman, bobot badan dan kecepatan pertumbuhan.

Hasil analisis ragam pada penelitian menunjukan bahwa level protein berbeda (14\% dan $18 \%$ ) dan penambahan zat aditif memberikan pengaruh yang berbeda tidak nyata $(\mathrm{P}>0,05)$, terhadap jumlah konsumsi pakan (g/ekor/hari). Hal ini diduga karena pakan yang diberikan berbentuk pellet sehingga tekstur, bau, rasa dan suhu sama. Hasil penelitian ini ditunjang oleh Church dan Pond (1988), palatabilitas yang meliputi tekstur, bau, rasa, dan suhu dari pakan yang diberikan, mempengaruhi tingkat konsumsi dari kelinci.

\section{Pertambahan Bobot Badan (PBB)}

Hasil penelitian menunjukkan bahwa pertambahan bobot badan kelinci berkisar antara 11,73 - 16,74 g/ekor/hari. Menurut (Cheeke, 1982) pertumbuhan kelinci di daerah tropis hanya sekitar 1020 g/ekor/hari, lebih rendah dibandingkan dengan kelinci negara Eropa dan Amerika yang pertumbuhannya mencapai $35-40$ g/ekor/hari. Aritonang dkk (2003) melakukan penelitian pada kelinci Rex, Satin, dan persilangannya, dimana PBBnya berkisar antara11,66 - 20,05 g/ekor/hari 
Hasil analisis keragaman menunjukkan bahwa interaksi perlakuan memberikan pengaruh yang berbeda nyata $(\mathrm{P} \leq 0,05)$ terhadap PBB,. Parakkasi (1999) menyatakan bahwa penambahan protein dalam ransum dapat meningkatkan pertambahan bobot badan sedangkan penambahan serat dalam ransum akan menurunkan bobot badan.

Hasil uji tukey menunjukan bahwa PBB kelinci yang mendapat pakan A2B3 16,74 g/ekor/hari (18\% protein dengan tambahan Enzim dan Asam Propionat) nyata lebih tinggi dibanding PBB kelinci yang mendapat pakan A1B3 11,73 g/ekor/hari (14 \% protein dengan tambahan Enzim dan Asam Organik). Hasil ini menunjukan bahwa penambahan enzim dan asam propionate pada pakan yang mengandung protein tinggi (18\%) memberikan respon yang lebih baik dibanding yang mengandung protein rendah $(14 \%)$. Hal ini diduga dengan penambahan asam propionate yang berfungsi sebagai acidifier lebih efektif pada pakan protein tinggi. Hal ini ditunjang oleh Tillman $d k k$ (1989) yang menyatakan faktor pakan sangat menentukan terhadap pertumbuhan bila kualitasnya baik dan diberikan dalam jumlah yang cukup, maka pertumbuhannya akan menjadi cepat, demikian pula sebaliknya.

\section{Konversi Pakan}

Konversi pakan merupakan salah satu tolak ukur untuk menilai tingkat efisiensi penggunaan pakan. Jika nilai konversi pakan yang ditunjukan tinggi, maka efisiensi penggunaan pakan rendah. Sebaliknya jika nilai konversi pakan rendah, maka efisiensi penggunaan pakan tinggi atau baik.

Konversi pakan pada penelitian ini berikisar antara 4,93 - 6,60 g/ekor/. Aritonang $d k k$ (2003), melakukan penelitian pada kelinci Rex, Satin, dan persilangannya menghasilkan konversi yang berkisar 4,11 - 7,11 g/ekor/hari. Hasil analisis ragam menunjukan bahwa perlakuan memberikan pengaruh yang berbeda tidak nyata $(\mathrm{P}>0,05)$. Hal ini menunjukan bahwa semua perlakuan memberikan pengaruh yang sama terhadap konversi pakan. Konversi pakan yang setara ini diduga karena pakan yang diberikan sudah sesuai untuk kebutuhan produksi ternak. Hal ini ditunjang oleh Campbell dan Lasley (1985) yang menyatakan bahwa konversi pakan dipengaruhi oleh kemampuan ternak dalam mencerna bahan pakan, kecukupan zat pakan untuk kebutuhan hidup pokok, pertumbuhan dan fungsi tubuh lain serta jenis pakan yang dikonsumsi. Faktor yang mempengaruhi tinggi rendahnya konversi pakan yaitu kualitas pakan, 
galur atau keturunan dan manajemen pemberian pakan (Anggorodi, 1985).

\section{KESIMPULAN}

$\begin{array}{rcrr}\text { Dari } & \text { penelitian } & \text { ini } & \text { dapat } \\ \text { disimpulkan } & \text { bahwa tidak } & \text { perlu }\end{array}$ penambahan feed additive pada ransum yang telah memenuhi kebutuhan zat-zat makanan baik pada level $14 \%$ dan $18 \%$ protein.

\section{DAFTAR PUSTAKA}

Anggorodi, R. 1985. Ilmu Makanan Ternak Umum. PT. Garuda Pustaka Utama. Jakarta.

Aritonang, D., N.A. Tul Roefiah, T. Pasaribu dan Y.C. Raharjo. 2003. Laju pertumbuhan kelinci rex, satin dan persilangannya yang diberi lactosym@ dalam sistem pemeliharaan intensif. JITV 8(3): 164-169.

Cheeke, P.R., N.M. Patton dan G.S Templeton. 1982. Rabbit Production. $5^{\text {th }}$ Ed. The interstate Printers \& Publisher, Inc., Danville.

Church, D.C. \& W.G.Pond. 1988. Basic Animal Nutrition and Feeding. 3rd ed Jhon Willey and Sons. New York.

Farrell, D.J. dan Y.C. Raharjo. 1984. Potensi ternak kelinci sebagai penghasil daging. Pusat Penelitian dan Pengembangan Ternak, Bogor.
García A.I., García J., Corrent E., Chamorro, S., García-Rebollar P., De Blas C., Carabaño R. 2005. Effet de l'âge du lapin, de la source de protéine et de l'utilisation d'enzymes sur les digestibilités apparentes de la matière sèche et de la protein brute sur un aliment lapin. In Proc.: 11èmes Journées de laRecherche Cunicole, Paris, France, 197-200.

Mastika, I. M. 2000. Ilmu Nutrisi Unggas. Penerbit Universitas Udayana, Denpasar

National Reseach Council. 1977. Nutrient Requirement of Rabbit. National Academic of Science, Washington.

Parakkasi, A. 1999. Ilmu Nutrisi dan Makanan Ternak Ruminan. Universitas Indonesia Press, Jakarta.

Piliang,W. G, D Sastradipradja dan W, Manula 1982. Pengaruh penambahan berbagai tingkat kadar $\mathrm{Zn}$ dalam ransum yang mengandung dedak padi terhadap penampilan serta metabolism $\mathrm{Zn}$ pada ayam-ayam petelur. Laporan Penelitian. Ditektorat Pembinaan penelitian dan pengabdian pada masyarakat.Direktorat jendralpendidikan tinggi departemen pendidikan dan kebudayaan.

Samadi. 2004. "Feed Quality for Food Safety", Kapankah di Indonesia?. Inovasi Online .vol 2 (XVI).

Steel, R. C. dan Torrie J. H. 1991. Prinsip dan Prosedur Statistika. Gramedia Pustaka Utama. Jakarta. 
Tillman, A.D., H. Hartadi, S. Mada University Press, Reksodiprodjo,

S. Yogyakarta.

Prwawirokusomo

L.

Lebdosoekojo. 1989. Ilmu

Xuan et al. (2001) Proc. Natl. Acad. Sci.

Makanan Ternak Dasar. Gajah

USA $98 \quad(16)$, 9050-

9055.10.1073/pnas.161283798) 